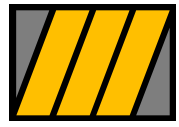

ESCUELA DE NEGOCIOS Universidad Torcuato Di Tella

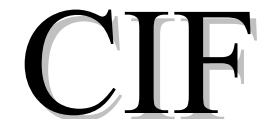

Centro de Investigación en Finanzas

Documento de Trabajo 03/2002

\title{
Financial globalization: Unequal blessings
}

\author{
Augusto de la Torre \\ World Bank \\ Eduardo Levy Yeyati \\ Universidad Torcuato Di Tella \\ Sergio L. Schmukler \\ World Bank
}
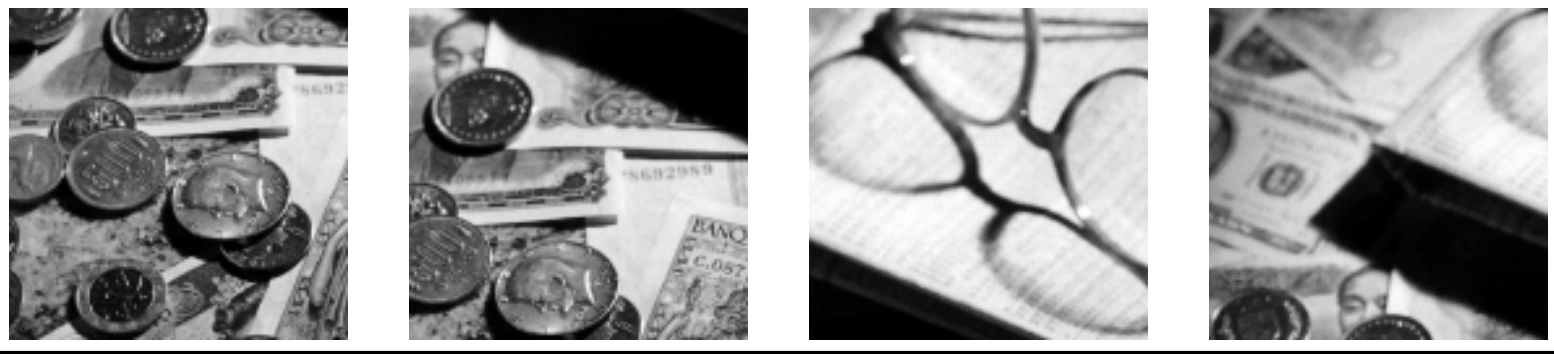

Miñones 2177, C1428ATG Buenos Aires • Tel: 4784.0080 interno 181 y 4787.9394 • Web 


\author{
Financial globalizati on: \\ UNEQUAL BLESINGS \\ Augusto de la Torre \\ World Bank \\ Eduardo Levy Yeyati \\ Universidad Torcuato Di Tella \\ and \\ Sergio L. Schmukler \\ World Bank
}

October 1, 2002

\begin{abstract}
This paper presents a framework to analyze financial globalization. It argues that financial globalization needs to take into account the relation between money (particularly in its role as store of value), asset and factor price flexibility, and contractual and regulatory institutions. Countries that have the "blessed trinity" (international currency, flexible exchange rate regime, and sound contractual and regulatory environment) can integrate successfully into the (imperfect) world financial markets. But developing countries normally display the "unblessed trinity" (weak currency, fear of floating, and weak institutional framework). The paper defines and discusses two alternative avenues (a "dollar trinity" and a "peso trinity") for developing countries to safely embrace international financial integration while the blessed trinity remains beyond reach.
\end{abstract}

JEL classification codes: F30, F31, F33, G20, G28

Keywords: financial globalization; dollarization; floating; currency regime; financial crises; emerging markets

\footnotetext{
${ }^{\otimes}$ We thank Benn Steil (the editor), Rick Mishkin, Guillermo Perry, Luis Servén, two anonymous referees, and seminar participants at the ECLAC (UN)-World Bank conference on globalization (Santiago, Chile 2002) and the World Bank 2002 Finance Forum for very helpful comments. We thank Marina Halac for excellent research assistance. The views expressed in this paper are entirely those of the authors and do not necessarily represent the views of the institutions where they work. E-mail addresses: adelatorre@worldbank.org, ely@utdt.edu, and sschmukler@worldbank.org.
} 


\section{Introduction}

Financial globalization, that is, the integration of countries into international financial markets, is not a new phenomenon. However, it is taking new forms and posing complex problems to emerging economies. This paper proposes a new framework to understand the challenges that emerging countries face as they integrate with the international financial system, as well as to discuss the realistic options open to them as they strive to control the risks of financial globalization while capturing its benefits.

\section{Historical ly, the gold standard period ( $1880-1914$ )} saw a naj or vave of fi nancial gl obalization, as cross- border capital flons surged, incorporating countries in the center and the peri phery into a worl dwide network of fi nance and i nvestnent. Wh the advent of the First World War, gl obal grouth hal ted and i nternati onal fi nancial i ntegration was di srupted, with nini nal capital novenent between 1914 and 1945 . A sl ow reconstruction of the vorld fi nancial system took place during the $B$ retton bods era (1945-1971), al though donestic fi nanci al narkets renai ned heavily regul at'ed and controls vere typically i nposed on capital fl ous. I t was not until the $1970 \mathrm{~s}$ that the world witnessed the begi nning of a new wave of i nternati onal fi nanci al integration, reflecting the di snantling of capital controls, de regul ati on in donesti c fi nancial systens, and revol uti onary technol ogi cal i nnovati ons ( not j ust in i nf ornati on and tel ecommoni cati ons but al so i n fi nancial product fi nancial gl obal ization with vigor starting in the latter part of the $1980 \mathrm{~s}$.

Costfel d and Tayl or $\left(\begin{array}{llll}2 & 0 & 0 & 2\end{array}\right)$ argue that the different hi storical phases of fi nanci al gl obal $i$ zati on can be understood i $n$ terns of the "i npossible trinity." 1 A ccording to this propositi on a country can consistently pursue only two out of the three policy objectives: free capital mobility, a fixed (or highly stable) nominal exchange rate, and an autonomous monetary policy. Obstfeld and Taylor explain that international capital mobility has, thus, prevailed in periods of political support either for subordinating monetary policy to exchange rate stability (as in the gold standard), or for giving up exchange rate stability so as to enable monetary policy to pursue domestic objectives (as in the post - B retton Woods era). In contrast, when countries attempted simultaneously to target their exchange rates and use monetary policy in pursuit of domestic objectives (e.g., to combat the slowdown of economic activity in the interwar period), they had to impose controls to curtail capital movements.

Obstfeld and Taylor characterize well the post-Bretton Woods process of financial globalization for developed countries. But emerging economies have lived a different reality. While they have tried a wide range of exchange rate arrangements - soft pegs, hard-pegs, crawls, bands, and flexible exchange rate systems - more recently, particularly since 1995, the share of emerging countries declaring themselves as having flexible exchange rates has been on the rise (Larraín and Velasco 2001). However, even countries that have opted for

\footnotetext{
${ }^{1}$ The concept of an impossible trinity is not new. It dates back, at least, to the work of Mundell in the 1960s.
} 
flexible arrangements in principle display "fear of floating" in practice ${ }^{2}$ and are thus unable to fully profit from an autonomous monetary policy. ${ }^{3}$ Moreover, emerging markets that have embraced financial globalization have in many cases been severely bruised by financial crises. Witness the crises in Latin America in the 1980s, Venezuela 1994, Mexico 1994-95, East Asia 1997-98, Russia 1998, Brazil 1999, Ecuador 1999, Turkey 2001, and Argentina 2001-02.

Although financial globalization alone cannot explain the frequency and severity of financial crises, its post-Bretton Woods incarnation has been associated with a rising incidence of twin (currency and banking) crises, and even triple (currency, banking, and debt) crises such as the recent ones in Ecuador and Argentina. ${ }^{4}$ The current wave of financial globalization has been, especially for the periphery, punctuated by painful episodes of capital flow reversals or "sudden stops." The integration of the domestic financial systems from middle-income countries into the world's financial markets has not led to the materialization of such promised benefits as a truly counter-cyclical monetary policy, consumption smoothing, deepening and diversification of their domestic financial markets, noticeable reduction in the cost of capital, and significant availability of long-duration financial contracts denominated in the domestic currency. ${ }^{5}$ In all, it is hard to escape the conclusion that the post-Bretton Woods wave of financial globalization has not worked as advertised for the periphery.

In this paper we argue that, under the current wave of financial globalization, the successes and failures experienced by countries as they integrate into international financial markets can be linked to the nature of interactions between three elements: (1) money, particularly in its role as store of value; (2) nominal (asset and factor price) flexibility; and (3) the quality of contractual and regulatory institutions. We introduce the notion of the "blessed trinity" (international currency, flexible exchange rate, and sound institutions), as a benchmark that defines conditions under which countries can integrate successfully into the world financial markets. In contrast, developing countries generally exhibit what we call the "unblessed trinity" (weak currency, fear of floating, and weak institutions), which sets them up for nasty experiences as they integrate into international financial markets. Inasmuch as it is difficult for these countries to reach the blessed trinity, we argue that, realistically, their option is to pursue either a "dollar trinity" or a "peso trinity," the achievement of which is enough of a complex challenge.

The rest of the paper is organized as follows. Section 2 examines the elements of the blessed trinity and how they interact to empower financial globalization. Section 3 analyzes the unblessed trinity and how it handicaps the ability of emerging countries to integrate

\footnotetext{
2 See, for example, Calvo and Reinhart (2002), Hausmann et al. (2001), and Levy Yeyati and Sturzenegger (2001).

${ }^{3}$ See, for example, Frankel, Schmukler, and Servén (2002).

${ }^{4}$ See, for example, Kaminsky and Reinhart (1999). Also, Bordo et al. (2001) show, for instance, that currency crises were more frequent during the Bretton Woods era (1945-1971), a period of low financial globalization, compared to the gold standard era (1880-1914), a time of high financial globalization.

${ }^{5}$ Obtsfeld (1998), Stulz (1999), and Mishkin (2001) discuss the benefits of financial globalization.
} 
successfully into the international financial system. Section 4 explores the dollar trinity and the peso trinity, and the pitfalls and options on the road to building them. Section 5 concludes.

\section{The Blessed Trinity}

The international finance literature has argued for a long time that financial markets, both domestic and international, are far from perfect. ${ }^{6}$ Finance is subject to problems like incomplete markets, asymmetric information, noise trading, bubbles, herding, multiple equilibria, moral hazard, and contagion. Some of these problems are more prevalent at the domestic level (like incomplete markets), while others are more prevalent when a country integrates with the international financial system (like asymmetric information and moral hazard) ${ }^{7}$

Despite these problems, a country can integrate successfully into the imperfect international financial markets to the extent that it exhibits the "blessed trinity," defined as the fundamental (mutually reinforcing) setup of: (1) international currency, (2) flexible exchange rate, and (3) sound contractual and regulatory environment. To these we turn next.

\subsection{Definitions}

An international currency is one that is accepted as a store of value both at home (so that it is used for domestic financial intermediation) and abroad (so that the country can issue local-currency denominated debt in international markets). This international stature is underpinned by credible macroeconomic policies and, in particular, by a sustainable fiscal process that ensures the solvency of the currency issuer.

A country has a flexible exchange rate if it allows its currency to float relatively freely against other currencies, without the need to hold large amounts of reserves of international currency ("life jackets") in an attempt to give credibility to the float. ${ }^{8}$ The effectiveness of the flexible exchange rate system is institutionally underpinned by a reputable central bank that pursues price stability. ${ }^{9}$

A sound contractual and regulatory environment $\mathbf{s}$ one that adequately minimizes principal-agent problems that are inherent to financial systems. ${ }^{10}$ It does so by ensuring contract enforcement (finance is contract-intensive) and reducing its costs, and by

\footnotetext{
${ }^{6}$ See, for example, Allen and Gale (2000a and 2000b), De Long et al. (1990), Obstfeld and Rogoff (1996).

${ }^{7}$ See Calvo (2002).

${ }^{8}$ See Calvo (2000a).

${ }^{9}$ One might argue that the optimality of a flexible exchange rate should be weighted against the gains from integration, which might be promoted by exchange rate coordination (in the form of a fixed exchange rate, $d e$ jure dollarization, or a monetary union). This does not change the basic point of the paper, namely that flexible exchange rates have the advantage of allowing a country to benefit from an autonomous monetary whenever the other two pillars of the blessed trinity are present.

${ }^{10}$ Ultimately, the soundness of the contractual and regulatory environment is directly linked to the quality and strength of government and of democratic institutions.
} 
minimizing information asymmetries. Contract enforcement is underpinned by clear shareholder and creditor rights and reflects the operation of the rule of law backed by a trustworthy judiciary. A sound regulatory environment reduces incentives for undue risk taking and looting through, among other things, good accounting and information disclosure standards, risk-based capital requirements, and private sector monitoring complemented by a type of official monitoring that is both rigorous and conducted in a manner that fosters risk awareness. It also features a financial safety net that carefully controls risk shifting to the government (moral hazard) while limiting contagion risk and fostering financial deepening.

\subsection{The Blessed Trinity Empowers Globalization}

A country blessed with the trinity can inte grate successfully into (imperfect) international financial markets because the components of the trinity interact in virtuous ways to control the risks of financial globalization while maximizing its benefits.

Being a credible store of value at home, the local currency becomes the axis around which domestic financial intermediation and contracting is effectively organized. This, complemented by sound regulatory and contractual institutions, gives rise to deep and liquid markets for long-duration, domestic-currency denominated financial assets (e.g., equity securities and long-term debt at fixed interest rates). As a result, currency and maturity mismatches can be minimized, which is key to reducing country risk and its volatility. In particular, househo lds and firms with incomes in the non-tradable sector can easily contract liabilities denominated in the domestic currency (or, more precisely, denominated in terms of non-tradables) at a reasonable cost. ${ }^{11}$

To the extent that the domestic currency is also a credible store of value abroad, the government and residents of a trinity-endowed country can issue debt denominated in the domestic currency in international markets. This simple but remarkable feat enables the domestic economy to deepen its financing sources as they access international capital markets, without incurring foreign exchange risk.

The combination of an international currency with a flexible exchange rate underscores two privileged policy capacities. The first is the central bank's ability to conduct counter-cyclical monetary policy (i.e., to smooth out cyclical output and employment fluctuations to the extent that monetary policy has transitory real effects). Note that this capacity stems from both elements of the trinity and not, as often believed, from exchange rate flexibility alone. In a world of highly mobile capital, giving up a policy of exchange rate stability may not suffice to enable the simultaneous achievement of the two other sides of the Mundellian trilemma, that is, complete financial openness and full monetary policy autonomy (including a counter-cyclical capacity). In contrast, we argue that an international currency is a sufficient condition to achieve counter-cyclical monetary policy in the context of a flexible exchange rate. This point will become clearer later on in this paper, as we discussed the features of the "unblessed trinity."

\footnotetext{
${ }^{11}$ The fixed-rate 30-year domestic-currency denominated mortgage loan is indeed a wonderful creature of the blessed trinity, and the object of healthy envy of trinity-challenged countries.
} 
The second is the ability of the blessed country to rapidly adjust the real exchange rate (i.e., the relative price of tradables to non-tradables) to a more depreciated equilibrium level, without unnecessary output losses and without significant balance sheet disruptions. As wages and goods prices are typically slow to adjust downwardly, flexibility in the nominal exchange rate permits a fast depreciation of the real exchange rate towards a new equilibrium, with the associated expenditure switching effects sparing the country from the unnecessary pain of having to adjust only through aggregate expenditure reduction and the resulting unemployment and deflation. ${ }^{12}$ Expenditure switching effects also imply that, for a blessed country that is temporarily suffering from excess capacity and unemployment, a real exchange rate depreciation will typically lead to an expansion in economic activity.

Moreover, as mentioned earlier, in a trinity-endowed country, households and firms whose income is derived from the non-tradable sector can easily borrow in the domestic currency (i.e., in terms of non-tradables). As a result, a real exchange rate adjustment through a nominal depreciation of the currency has favorable balance sheet effects as it reduces the real value of their outstanding localcurrency debts. These salutary balance sheet (stock) effects reinforce the above-mentioned positive (flow) effects of a real exchange rate depreciation on economic activity. At the same time, tradable-sector firms can avoid currency mismatches by hedging their domestic-currency liabilities in well-functioning spot and derivatives markets (whose presence is a consequence of the international nature of the domestic currency) or by borrowing in foreign currency (i.e., denominating their debts in terms of tradables). ${ }^{13}$

Given the international acceptance of the domestic currency, the central bank can provide last resort assistance to its banking sector by borrowing both domestically or abroad, thus fending off unnecessary contagious runs while avoiding the recourse to the inflationary tax. This validates the type of financial stability that is a precondition for the bcal currency to be attractive internationally.

The combination of a reputable central bank with savings that are invested in local currency assets curbs the risk that governments would succumb to time inconsistency (i.e., the incentive to inflate away its liabilities after having issued them), as the benefits of defaulting on their debts through inflation are overshadowed by short- and long-run economic and political costs if the value of the savings of their influential constituencies (e.g., pension fund beneficiaries) are eroded through surprise inflation. The trinity thus protects savers, who respond by sticking to the local currency as a store of value for their savings.

Few countries in the world (United States, Germany followed by the European Unio n, England, Japan until recently) are blessed with the trinity and can thus embrace financial

\footnotetext{
12 As Friedman (1953) keenly noted in his classic defense of flexible exchange rates, adjusting the nominal exchange rate upward is superior to adjusting nominal wages and prices downward for analogous reasons that the automatic move to daylight savings time is easier than coordinating the will of a large number of people to begin all habitual activities one hour earlier.

13 Recall that the payments for international trade and financial contracts are typically settled in hard, international currencies.
} 
globalization in a relative safe manner and reap its benefits, in spite of the highly deficient international financial architecture.

\section{The Unblessed Trinity}

At the other extreme, dramatically far from the blessed trinity, are typically open (to trade and finance) and unstable emerging economies that exhibit the "unblessed trinity," defined as the perverse interaction of: (1) weak currency, (2) limited exchange rate flexibility ("fear of floating"), and (3) weak contractual and regulatory environment. For unblessed countries, integrating into international financial markets is a perilous affair.

\subsection{Definitions}

An unblessed emerging economy has a weak currency, that is, a currency that is not accepted either internationally or domestically as a reliable store of value. Even after years of low inflation, domestic investors in the unblessed country shy away from local-currencydenominated financial assets (financial dollarization). ${ }^{14}$ As a result, non-tradables producers end up with debts denominated in tradables - a most troublesome version of "liability dollarization." On the other hand, when domestic dollar intermediation is restricted by outright prohibition or regulatory controls, a country with a weak currency displays pronounced short-termism in financial contracts that re-price very frequently (e.g., deposits with interest rates that adjust daily in line with the overnight rate). In sum, a weak currency leads to financial fragility since, as markets for long-duration, domestic-currency financial assets are virtually non-existent, currency or maturity mismatches in the domestic financial system are inevitable. ${ }^{15}$

A country with the unblessed trinity has fear of floating. Even those declaring to have a flexible exchange rate systematically reveal a preference for exchange rate stability, heavily relying on interest rate policy and foreign exchange intervention to limit fluctuations in the exchange rate. Calvo and Reinhart (2001) discuss the factors underlying this preference. In financially dollarized economies where non-dollar earners are indebted in dollar, a discrete depreciation may generate corporate and household bankruptcies and, consequently, bank failures, with serious fiscal consequences. This is aggravated by the fact that the central bank's capacity to fulfill the role of lender of last resort without inflationary costs is limited to its capacity to be a borrower of last resort, itself curtailed by the procyclicality of international capital markets vis-à vis weak-currency countries. ${ }^{16}$ On the

\footnotetext{
${ }^{14}$ On the pervasiveness of financial dollarization in emerging economies, see Baliño et al. (1999) and Ize and Levy Yeyati (2001). Note that, without loss of generality, we use the dollar to denote any internationally accepted currency.

15 The coexistence of maturity and currency mismatches, perhaps the main manifestation of the weak-currency problem, relates to Eichengreen and Hausmann's (1999) "original sin," that is a situation in which the domestic currency cannot be used to borrow abroad or to borrow long term, even domestically. The origin of the weakcurrency problem relates to various factors, including the existence of incomplete markets, and the combination of weak institutions and moral hazard (namely, the temptation to reduce fiscal obligations through inflation).

${ }^{16}$ Indeed, when central banks in unblessed economies try to fulfill this role they tend to aggravate balance-sheet problems by fueling the depreciation of the local currency. This, in turn, feeds back on the weakness of the
} 
other hand, depreciations tend to be avoided also because of their adverse impact on inflation due to the propensity for dollar indexation in inflation-prone, financially dollarized economies. In addition, as argued by Calvo and Reinhart (2002), policy makers may prefer exchange rate to interest rate stability since by doing so they provide the economy with a readily verifiable (hence, more credible) nominal anchor. ${ }^{17}$

The third component of the unblessed trinity is the presence of weak institutions that yield a deficient contractual and regulatory environment. The unblessed country rates poorly in terms of rule of law and its judiciary is unreliable and plagued by corruption. Fiscal, monetary, and regulatory institutions are weak, reflecting deeper weaknesses in overall governance and democratic institutions. Central banks are subject to political maneuvering. Accounting and disclosure practices are sub-standard, and shareholder rights and creditor rights are ill defined and poorly enforced. As a result, principalagent and information asymmetry problems are severe, fostering excessive risk taking and looting in the financial system, thus compounding the vulnerabilities that stem from the poor performance of its currency as a store of value. ${ }^{18}$

\subsection{The Unblessed Trinity Handicaps Globalization}

The above elements conspire to intensify risks as the unblessed country integrates into international financial markets. This is due to a web of vicious interactions and feedback loops between the elements of the unblessed trinity that result in fragile macro-financial conditions and a financial system highly vulnerable to shocks and self-fulfilling attacks.

Due to fear of floating, international reserves in unblessed countries provide a "double guarantee," for bank deposits and for the currency. This, as Dooley (2000) shows, heightens the country's vulnerability to speculative attacks - that is, a crisis caused by a devastating run engineered at a time where there are no perceptible changes in fundamentals, by agents that, to avoid capital losses, anticipate the inevitable. ${ }^{19}$

Unblessed countries are typically (and increasingly) affected by financial (deposit and loan) dollarization, to some extent a by-product of the interaction of financial globalization with unblessed trinities. ${ }^{20}$ Financial globalization, by giving access to a large pool of foreign funds, only intensifies the dilemma between high-cost short-duration peso debts (with the associated interest rate risk) and more affordable dollar debts (with the associated currency risk). In turn, weak institutions distort the process of risk pricing (for example, by creating the perception of implicit public guarantees against the event risk associated with a sharp

currency, exacerbating the fear to float, the counter-cyclicality of monetary policy, and the perceived need for "life jackets." See Calvo (2000b).

${ }^{17}$ Emerging countries may also want to avoid large appreciations. That is, fear of floating in times of buoyant capital inflows can reflect concerns with loosing international competitiveness (Dutch-disease-type problems).

${ }^{18}$ See, for example, Mishkin (2001) and Akerlof and Romer (1993).

${ }^{19}$ See also Aghion et al. (2001) and Burnside et al.(2001).

${ }^{20}$ Baliño et al. (1999) find that, by 1995, foreign-currency deposits exceeded on average 45 percent of M2 in 18 countries, and were on average over 16 percent of M2 in other 34 countries. Honohan and Shi (2002) find that deposit dollarization has continued to increase since then in most countries that allow dollar deposits. 
depreciation of the currency), inducing a preference for the first source of funds, and, as stressed by McKinnon and Pill (1997), over-borrowing in the foreign currency. ${ }^{21}$

In turn, in a financially dollarized economy, a sharp depreciation can not only unleash inflation, but also erode the solvency of dollar debtors in the non-tradable sector harming the banking system (and the fiscal accounts to the extent of the existing safety nets) in the process. A similar dynamic is to be expected from a dollar-indebted public sector. Hence, the negative feedback between real depreciation and insolvency undermines the stability properties of the real exchange rate and outweighs any expansionary effect of a real depreciation on economic activity. ${ }^{22}$

It is precisely the adverse real impact of a nominal devaluation, rooted in the weakness of the local currency that underlies the well-known procyclicality of capital markets faced by developing countries. Indeed, as the capacity to pay of the country as a whole is positively correlated with the exchange rate, it is compelled to play the "credibility game" and raise interest rates during times of economic recession to convince investors not to flee the currency. ${ }^{23}$ Access to international capital markets, inasmuch as they increase the flows to and from the domestic economy, only accentuates the procyclical nature of monetary policy in an unblessed country.

In sum, the unblessed trinity is associated with a severe problem of missing markets - for the country's currency, for long-term domestic-currency denominated finance, and for hedges and other insurance products, among others. As a result, financial globalization tends to magnify the deficiencies in both domestic policies and institutions and the international markets themselves, leading to a higher incidence of multiple equilibria problems, sudden stops, and self-fulfilling runs.

While some emerging countries may be able to eventually achieve the blessed trinity in the long run, for most of them the blessed trinity appears to be an impossible dream. In the next sections we argue that developing countries are, however, not without options, for they can work on either one of two more realistic solutions: the "dollar trinity" and the "peso trinity."

\section{Two Trinities for the Unblessed}

Unblessed countries may be tempted to conclude that they should isolate themselves from financial globalization. But that is certainly not a desirable option, and possibly also not a feasible one. A country completely isolated from international capital and financial

\footnotetext{
${ }^{21}$ In addition, credit and asset bubbles exacerbate information asymmetry problems and plant the seeds for subsequent crises. See Gavin and Hausmann (1996).

22 Ecuador's 1999 crisis illustrates the dire consequences of floating with liability dollarization and a weak fiscal position. The crisis deepened dramatically as devaluation and debtor insolvency were caught in a feedback loop, leading the real exchange rate to spiral away (De la Torre, García-Saltos, and Mascaró 2002). The exchange rate vulnerability of financially dollarized economies has been the subject of much recent debate. See, e.g., Mishkin (1999), Calvo (2000b), and, more recently, De la Torre, Levy Yeyati, and Schmukler (2002).

${ }^{23}$ Evidence on this is presented in Hausmann et al. (2001).
} 
services is likely to be poorer and with poorer growth prospects than even unblessed countries attempting to integrate, partly because the latter would be under constant external pressure to improve their domestic policies and institutions. Moreover, given the speed of financial innovation, it is doubtful that capital controls can successfully keep domestic residents locked away from international financial markets. Finally, it would be selfdefeating to systematically scare away foreign direct investment and financing.

The problem for an emerging economy, thus, is not whether but how to integrate into world financial markets. Part of the answer has been implicitly given in the previous sections: by striving to establish the blessed trinity or at least mimicking its main features, or by taking actions whose effects compensate for the missing components. Depending on which of them is deemed more relevant two alternatives appear feasible. Both focus on the exchange rate.

Economists are divided into advocates of flexible exchange rate regimes and advocates of hard pegs or outright dollarization. The discussion below adds to the debate by squarely putting exchange rate issues in the context of financial globalization. From that point of view, we argue that there are two viable trinities for the unblessed: the "dollar trinity" and the "peso trinity." Although still distant from the blessed trinity, these options constitute a major improvement over the unblessed trinity in facilitating a successful financial globalization for emerging markets.

The dollar trinity focuses on the weak-currency problem. Its premise is that, since the local currency is not to fulfill the role of store of value in the foreseeable future, formal (unilateral) dollarization is adopted as a means to establish an unquestioned store of value to foster on-shore financial intermediation. In this context, the difficult challenge lies in recomposing the other two sides of the trinity-i.e., gaining adequate nominal flexibility, particularly as regards wages and fiscal spending, and building sound institutions.

The peso trinity focuses on the issue of fear of floating. Its premise is that fear can and should be overcome, mainly through inflation targeting. The difficult challenge then shifts towards recomposing the other two parts of the trinity-i.e., establishing the domestic currency as the store of value to underpin a sustainable financial deepening (a task complicated by financial globalization itself, which magnifies the advantages of the dollar as receptacle of savings) and building sound institutions.

We set high standards for these two unblessed trinities. For instance, Ecuador is formally dollarized but is far from qualifying for the dollar trinity. In contrast, a well functioning example of a dollar trinity in our view would be Hong Kong. Similarly, Argentina is currently formally pesified but very far from meeting the standards for the peso trinity. Well-functioning examples of the peso trinity would be Australia and Chile. ${ }^{24}$

\footnotetext{
${ }^{24}$ Note that these two trinities are related but do not fully overlap with those proposed by the bipolar view (fully floating or super fixed exchange rates). See Fischer (2001) and references therein.
} 


\subsection{The Peso Trinity}

Optimal currency area (OCA) considerations ${ }^{25}$ are crucial to identify unblessed countries that should naturally strive along the path towards the peso trinity. Thus, the peso trinity is a goal that better suits a trinity-challenged country that has a relatively large nontradable sector, trades with countries in different hard currency zones, and is subject to significant idiosyncratic real shocks-i.e., shocks that are uncorrelated to those in countries with which it trades. The advisability of pursuing the peso trinity would be clearly reinforced where these OCA conditions coexist with a low level of financial dollarization.

The above conditions would enhance the capacity of inflation targeting to boost the role of the domestic currency as a store of value around which markets for longer-duration financial contracts can be organized. Also, the greater variability of the exchange rate associated with inflation targeting would reduce incentives for financial dollarization. ${ }^{26}$ As a result, inflation targeting would more effectively help the country absorb shocks (including sudden stops) by facilitating the adjustment of its real exchange rate to the post-shock equilibria.

But building these virtuous capacities is likely to be much more difficult than militant partisans of exchange rate flexibility care to accept, even if the mentioned OCA and low financial dollarization conditions are obtained. A ky reason was mentioned earlier. The unblessed country might have avoided financial dollarization mainly because its government systematically fostered, for instance, (i) the emergence of peso financial contracts of extremely short duration, and (ii) the transfer of currency mismatches from the private sector to the public sector. The government's balance sheet would thus concentrate significant unhedged currency and interest rate risks. If so, fear of floating would not be that easy to overcome through inflation targeting. More importantly, the enhancement of the role of the domestic currency as store of value to underpin long-term peso finance would necessarily call for a significant fiscal effort. In effect, the government would need to generate higher primary surpluses to afford the costs of changing the composition of its debt in favor of longer-term fixed-interest-rate peso obligations, and in order to generate a reliable yield curve for peso interest rates.

Things get more complicated (but not ompletely hopeless) if significant financial dollarization is part of the initial conditions of the unblessed country pursuing the peso trinity. Inflation targeting would then face much tighter constraints since financially dollarized economies with an inflation target cannot afford wide exchange rate fluctuations due to their deleterious effect on inflation. ${ }^{27}$ And the scope for generating substantial financial intermediation in the local currency is likely to be modest. In effect, skepticism on the feasibility of a voluntary reversal of financial dollarization in emerging markets appears

\footnotetext{
${ }^{25}$ See Mundell (1961).

${ }^{26}$ Ize and Levy Yeyati (2001) show that financial dollarization depends on the volatility of inflation relative to that of the real exchange rate (i.e., the volatility of real returns in peso financial assets relative to those in dollar assets).

27 The problem is more general. As Chang and Velasco (2000) put it, "any scheme to control the rate of inflation at a short horizon must control, to some extent, the nominal exchange rate."
} 
justified given the dearth of real life examples (despite progress towards macroeconomic stability) and the fact that financial dollarization has been generally rising pari passu with financial globalization. ${ }^{28}$ Nonetheless, it is increasingly recognized that inflation targeting could still operate, albeit in a highly constrained manner, in a country with significant financial dollarization, as long as real dollarization (i.e., the indexation of domestic prices to a foreign currency) is low and the local currency is used for transactions. ${ }^{29}$

The establishment of the domestic currency as store of value entails a much more complex challenge, which could be realistically achie ved only after a long track record of successful inflation targeting, complemented along the way by "policy crutches" (see below) and by considerable institutional strengthening. Indeed, for smaller open economies already affected by high financial dollarization (even if they display low real dollarization) and mainly subject to symmetric real shocks, recomposing financial intermediation around the domestic currency appears to be a prospect of little realism.

Note that we are not saying that moving away from fear of floating towards greater exchange rate flexibility is not a net gain for an unblessed country (it is), but rather that such a move is not sufficient to achieve the peso trinity. This consideration points to a potentially important trade off, mamely, that in some cases policy efforts wasted in an ultimately futile effort to achieve the peso trinity could be more efficiently employed in the pursuit of the dollar trinity, discussed in the next section.

At any rate, where the peso trinity remains a feasible goal, complementary "policy crutches" are likely to be needed, as noted by Goldstein's (2002) well-articulated a proposal for "managed floating plus." $\mathrm{He}$ recommends accompanying inflation targeting with "aggressive measures to reduce currency mismatching." Such measures would include prudential norms (e.g., provisions and capital rules) designed to discourage banks from taking on unhedged exposures to currency risk, either directly in their balance sheets or indirectly through the balance sheets of their unhedged debtors.

In addition, the government should systematically strive (and be willing and able to pay the associated cost) to raise the share of long-duration peso debts in their liability portfolio and encourage the development of domestic bond markets. Allowing the indexation of financial contracts (for example, to the CPI) can stimulate long-term savings and financing in the local currency. ${ }^{30}$

In sum, the road to the peso trinity is not easy and may not be part of the feasible set for some unblessed countries. While achieving a reasonable degree of exchange rate flexibility is an important step in that direction, the most difficult challenge, however, is to

\footnotetext{
${ }^{28}$ Honohan and Shi (2002) find recent and important reversals in financial dollarization in a handful of Eastern European countries, including Estonia, Lithuania, and Poland. How much of these reversals are transitory and/or related to prospects of joining the European Union is, however, yet to be ascertained.

${ }^{29}$ For a theoretical discussion of this issue, see Ize and Parrado (2002).

${ }^{30}$ As Ize and Levy Yeyati (2001) show, CPI indexation of financial assets, properly implemented, tends to dominate dollar indexation, as witnessed in the case of Chile, where UF deposits were systematically preferred to dollar deposits, preventing financial dollarization.
} 
nurture the peso as a store of value. A strong record of consistent, credible macroeconomic policy (including temporary policy crutches) is crucial, and so is the continuous improvement in the quality of regulatory and contractual environment. The light at the end of the tunnel would be that of a functional peso trinity.

\subsection{The Dollar Trinity}

Again, OCA-type considerations help identify unblessed countries that are naturally suited to pursue the dollar trinity. These are the smaller and highly open countries (i.e., with relatively small non-tradable sectors), whose trade is mainly with a country or countries in the same hard currency zone, and that are subject mainly to symmetric (rather than idiosyncratic) real shocks. The advisability of pursuing the dollar trinity would be reinforced if the country in question has a high degree of financial dollarization. However, the path towards the dollar trinity may also have to be pursued by emerging economies that already display inconsistencies between their trade and financial structures. That would be, for instance, the case of unblessed countries that were compelled to dollarize formally in the midst of a crisis, in order to avoid total financial disintermediation, even though their OCAtype features make pegging to the dollar highly inconvenient. ${ }^{31}$

Taking a step in the direction of the dollar trinity by formally dollarizing can correct in a single move the problems created by a weak currency, thereby automatically equipping the unblessed country with one, but only one, of the components of the blessed trinity. Formal dollarization can facilitate financial intermediation and deepening and foster the lengthening of maturities in financial contracts. By dampening capital flow volatility associated with perceived currency risk, dollarization can reduce the scope for multiple equilibria, thereby limiting the probability of self-fulfilling attacks, sudden stops, and financial crises. ${ }^{32}$

While formal dollarization can sever the direct link between fiscal solvency and the currency as store of value (see below), it does not itself eliminate the indirect links between fiscal viability and the financial system. Not only does a bad fiscal policy raise country risk and adversely affect local debt markets but, to the extent that local banks hold claims on the government, also increases the exposure of the banking system to sovereign default. Moreover, dollarization does not automatically lead to fiscal discipline, and fiscal indiscipline can feed back adversely into the dollarization arrangement itself. As the Argentine case illustrates, it is virtually impossible to prevent some variety of money printing when the resources to finance the fiscal deficit run out, contradicting the view of dollarization as an irreversible commitment mechanism. ${ }^{33}$

\footnotetext{
${ }^{31}$ Frankel (1999), following the dictum that "no one size fits all," notes that dollarization could be a desirable alternative for countries in which the currency could never be a store of value due to either a history of hyperinflation, the absence of strong institutions, or high exposure to nervous international investors.

32 Ecuador's experience in 2000 illustrates that formal dollarization can arrest the erosion in fundamentals and put a floor to runaway financial turbulence, even where fiscal and government debt problems remain unsolved.

${ }^{33}$ In Argentina, this took the form of issuance of small-denomination (provincial and federal) bonds accepted for tax payments, which by the end of the first quarter of 2002 amounted to 45 percent of the stock of currency in circulation. See de la Torre, Levy Yeyati, and Schmukler (2002).
} 
There are other significant tradeoffs of dollarization that are typically downplayed by dollarization advocates. First, dollarization limits the capacity of the central bank to fulfill the role of lender of last resort. While a weak currency country can play this role at the expense of inflationary pressures, formal dollarization eliminates even this source of protection of the payments system. Second, dollarization means giving up the hope for counter-cyclical monetary policy, no matter how distant that possibility might have been for a trinity-challenged country (see sections above). Third, it imposes tight limits on the country's ability to adjust rapidly the real exchange rate in the face of adverse shocks (a particularly troublesome aspect for countries that do not meet the OCA criteria and, therefore, are subject to significant shifts in the equilibrium real exchange rate). As long as downward price rigidities exist, the adjustment would take place slowly overtime through unemployment and deflation, with high real interest rates that would depress the economy even further. ${ }^{34}$ When a protracted recession and deflation finally drive home the real value of income and wealth in terms of tradables, it might be too late and the country may face the danger of the same self-fulfilling attacks it sought to immunize itself against when it adopted formal dollarization. Finally, the reported value of debt would be understated (capacity to pay overstated) relative to the equilibrium value of non-tradable income, which would mask the need for, and delay the implementation of, timely adjustment in spending.

These pitfalls make it clear that, in addition to the continued implementation of sound fiscal policies and general institution building, the pursuit of the dollar trinity needs especial complements to: (i) deal with dollarization-specific risks, (ii) maximize dollarization-specific benefits, and (iii) achieve an adequate degree of nominal flexibility. The importance of these complements is greater the less the country meets the OCA-type criteria.

Among the measures to deal with dollarization-specific risks, two are worth mentioning. First, there is the need to design prudential norms to address the risk of dollar lending to the non-tradable sector, considering that dollarization does not immunize a country from the balance sheet effects of a real exchange rate depreciation (Roubini 2001; Chang and Velasco 2000). As an overvalued real exchange rate understates the nonperformance of loans to non-tradable producers, prudential norms are needed to anticipate and manage the deterioration of the quality of such loans in the event of a shock that requires a real exchange rate depreciation. These norms can take the form of tougher loan classification criteria, higher loan-loss provisioning rules, and possibly also a higher weight for the purposes of measuring capital requirements for loans to the non-tradable sector. ${ }^{35}$ This prudential approach, however, eliminates debt deflation risks only partially, and at the expense of higher borrowing costs for non-tradables producers.

\footnotetext{
${ }^{34}$ Krugman (2001) argues that this has affected both Japan and Argentina.

35 The provisioning system could be designed with counter-cyclical features. That is, counter-cyclical provisions could be built during times of credit bonanza (which typically entail booming credit to the nontradable sector and are accompanied by an appreciating real exchange rate), and then allowed to be converted into specific provisions in times of credit slowdown (which are typically accompanied by a depreciating real exchange rate and thus entail a decay in the quality of loans to the non-tradable sector).
} 
Second, there is the need to adequately protect the payment system in a dollarized economy, given the lack of a lender of last resort. As the Argentine crisis illustrates, general liquidity requirements (i.e., available to any and all deposits, on a first come first served basis), even if high, may not adequately protect the payments system from a run. ${ }^{36}$ It thus would appear that, under financial dollarization, such protection might require prudential norms that give some form of priority of claim over available liquidity to transactional deposits, that is, to deposits that are germane to the functioning of the payment system. This does not necessarily require a narrow-bank type structure. It could also be achieved, for instance, by a rule that, under specified conditions, earmarks available liquidity to demand deposits. While the operationalization of this concept does not appear to be easy, the prudential principle on which it is based warrants serious consideration. The objective of such prudential innovation would be to preserve the functioning of the payment system, even in the extreme scenario in which banks are unable to honor withdrawals of time deposits.

One dollarization-specific benefit is that, in principle, it can protect banking intermediation from the vagaries of the fiscal process, including an event of government debt default, as long as banks are not significantly exposed to domestic government risk. The reason is that the function of the dollar as store of value does not depend directly on the solvency of the domestic government. ${ }^{37}$ This feature should be harnessed through prudential norms, for example by assigning a positive weight to banks' exposure to the government for the purposes of calculating capital requirements, or by introducing limits to such exposure. ${ }^{38}$

Finally, there is a need to build adequate nominal flexibility along the path towards establishing the dollar trinity for two main reasons. First, to facilitate the adjustment in the real exchange rate (through nominal wage correction) towards a more depreciated equilibrium level. Second, to facilitate the adjustment of nominal fiscal spending to income so as to ensure debt sustainability. Undoubtedly, reforms that enhance labor market flexibility and strengthen fiscal institutions are central to this endeavor. However, the realities of political democracy may severely constrain the margin to reduce nominal wages and fiscal expenditure, especially in the context of a recession.

It is therefore important to recognize that, under circumstances of extreme stress, political limitations on nominal flexibility can confront a dollarized country with major pressures to "exit" dollarization. This raises a most relevant question for countries pursuing the dollar trinity, particularly for countries that are far from meeting the conditions for an optimal dollar area. That is, the question of whether an "exit" towards greater flexibility could be engineered in a way that does not obliterate financial intermediation. We consider this issue at large in another paper and conclude that dollarization is not inherently

\footnotetext{
${ }^{36}$ To be sure, high liquidity requirements do enhance the resiliency of a banking system—-they cushion it vis -à vis liquidity shocks and deter runs, reducing the scope for multiple equilibria.

${ }^{37}$ Panama illustrates a case where a prolonged default in government debt did not affect the functioning of the banking system.

${ }^{38}$ Even in this case, fiscal problems can spill over into the banking system through direct confiscation of bank liquidity or bank deposits. Ultimately, no prudential norm (or, for that matter, no domestic law) can restrict the actions of a sovereign state if they can be reverted by the sovereign. This point is stressed in Mishkin and Savastano (2001).
} 
incompatible with a process of "pesification at the margin". ${ }^{39}$ This process (grounded theoretically and empirically on the distinction between money as a means of payment and money as a store of value) would result in a bi-monetary regime, where the dollar remains as the main currency for financial contracts while a national currency is introduced (either spontaneously or by design) and used mainly for transaction purposes. ${ }^{40}$ The sustainability of "pesification at the margin" would hinge on strong and viable fiscal institutions, a prudential framework to effectively address the risks of dollar loans to the non-tradable sector (as noted above), and a monetary policy that credibly pursues inflation targeting without disregarding the output cycle. ${ }^{41}$

\section{Closing Remarks}

The blessed trinity may be unreachable for many emerging markets but there are some blessings for the unblessed, as long as they undertake bold and consistent reforms. Countries cannot go wrong by strengthening their domestic institutions. But they would be better off by adopting either the dollar trinity or the peso trinity up front and undertaking the necessary institutional reforms that complement them. Intermediate solutions (e.g., soft pegs), or the pursuit of only one side of the trinity (e.g., outright dollarization or the floating of a weak currency, without much else), are likely to detract from the benefits of financial globalization, if not turn them negative.

The international financial community has an important role to play in enabling emerging countries to achieve successful financial globalization. International financial organizations can help not only by speeding up the pace of reforms within emerging markets but also by pressing for improvements in the international financial architecture. Developing countries, as they globalize, have fewer policy instruments, and need to coordinate with other countries to maximize the benefits of globalization while limiting financial vulnerability. Improving the international financial architecture would thus disproportionately benefit trinity-challenged emerging economies. Unfortunately, trinity-endowed industrial countries, which have economic and geopolitical power to address the flaws in the international financial architecture, have little incentive to do so if not threatened by financial contagion. ${ }^{42}$ At the same time, the recent disappointing experiences of emerging economies may induce a backlash in the process of financial integration. In the end, this incentive problem shifts responsibility to multilateral agencies. The question is whether they are up to the challenge.

\footnotetext{
39 See De la Torre, Levy Yeyati, and Schmukler (2002) for a detailed discussion of "pesification at the margin" as part of an analysis of lessons from the Argentine crisis.

${ }^{40} \mathrm{Bi}$-monetary regimes of this sort have de facto emerged in Latin America, as illustrated, for instance, by the cases of Bolivia, Costa Rica, Guatemala, Perú, and Uruguay, where the domestic currency is used for transactions while the dollar is the currency of denomination for most financial contracts.

${ }^{41}$ Ize and Parrado (2002) show that an inflation targeting policy that takes into account the cycle is a necessary condition to avoid real dollarization - that is, the indexing of wages and prices to the dollar.

${ }^{42}$ For example, developed countries have few incentives to transfer resources to a truly international lender of last resort if they believe that emerging countries are going to be the only ones using such lending facility.
} 


\section{References}

Aghion, Philippe, Philippe Bachetta, and Abhijit Banerjee, 2001, "Currency Crises and Monetary Policy in an Economy with Credit Constraints," European Economic Review, 45:7, pp. 1121-1150.

Akerlof, George, and Paul Romer, 1993, "Looting: The Economic Underworld of Bankruptcy for Profit," Brookings Papers on Economic Activity, 2, pp: 1-60.

Allen, Franklin, and Douglas Gale, 2000a, "Bubbles and Crises," The Economic Journal, 110:460, pp. 236-255.

Allen, Franklin, and Douglas Gale, 2000b, "Financial Contagion," Journal of Political Economy, 108:1, pp. 1-33.

Baliño, Tomás, Adam Bennett, and Eduardo Borensztein, 1999, "Monetary Policy in Dollarized Economies," Occasional Paper No. 171, International Monetary Fund, March.

Bordo, Michael, Barry Eichengreen, Daniela Klingebiel, and Maria Soledad MartinezPeria, 2001, "Is the Crisis Problem Growing Severe?," Economic Policy, April.

Burnside, Craig, Martin Eichenbaum, and Sergio Rebelo, 2001, "Hedging and Financial Fragility in Fixed Exchange Rate Regimes," European Economic Review, 45:7, pp. 1151-1193.

Calvo, Guillermo, 1998, "Capital Flows and Capital Market Crises: The Simple Economics of Sudden Stops," Journal of Applied Economics, CEMA, Argentina, 1:1, pp. 35-54.

Calvo, Guillermo, 2000a, "Capital Markets and the Exchange Rate: With Special Reference to the Do llarization Debate in Latin America," mimeo, University of Maryland.

Calvo, Guillermo, 2000b, "The Case for Hard Pegs in the Brave New World of Global Finance," mimeo, University of Maryland.

Calvo, Guillermo, 2002, "Globalization Hazard and Weak Government in Emerging Markets,” IADB Working Paper, February.

Calvo, Guillermo A., and Carmen Reinhart, 2001, "Fixing for Your Life," Brookings Trade Forum.

Calvo, Guillermo, and Carmen M. Reinhart, 2002, "Fear of Floating," Quarterly Journal of Economics, 117:2.

Chang, Roberto, and Andrés Velasco, 2000, "Exchange-Rate Policy for Developing Countries," American Economic Review, 90 (May), pp. 71-75. 
De la Torre, Augusto, Roberto García-Saltos, and Yira Mascaró, 2002, "Banking, Currency, and Debt Meltdown: Ecuador Crisis in the Late 1990s," in process.

De la Torre, Augusto, Eduardo Levy Yeyati, and Sergio Schmukler, 2002, "Living and Dying with Hard Pegs: The Rise and Fall of Argentina's Currency Board," forthcoming in Economia.

De Long, J. Bradford, Andrei Shleifer, Lawrence H. Summers, and Robert Waldmann, 1990, "Noise Trader Risk in Financial Markets," The Journal of Political Economy, 98:4; pp. 703-738.

Dooley, Michael P., 2000, "A Model of Crises in Emerging Markets," The Economic Journal, 110:460, pp. 256-272.

Eichengreen, Barry, and Ricardo Hausmann, 1999, "Exchange Rates and Financial Fragility," NBER Working Paper No. 7418, November.

Fischer, Stanley, 2001, "Exchange Rate Regimes: Is the Bipolar View Correct?" Distinguished Lecture on Economics in Go vernment, delivered at the AEA meetings in New Orleans on January 6, 2001.

Frankel, Jeffrey, 1999, "No Single Exchange Rate Regime is Right for All Countries or at All Times," Graham Lecture, Princeton University. Essays in International Finance No. 215, Princeton University Press: Princeton, August 1999.

Frankel, Jeffrey, Sergio Schmukler, and Luis Servén, 2002, “Global Transmission of Interest Rates: Monetary Independence and the Currency Regime," NBER Working Paper No. 8828, March.

Friedman, Milton, 1953, "The Case for Flexible Exchange Rates," in Ronald MacDonald and Mark Taylor (eds.), Exchange Rate Economics, Vol 1.

Gavin, Michael, and Ricardo Hausmann, 1996, "The Roots of Banking Crises: The Macroeconomic Context,” IADB Working Paper No. 318, January.

Goldstein, Morris, 2002, “Managed Floating Plus,” Institute for International Economics.

Hausmann, Ricardo, Ugo Panizza, and Ernesto Stein, 2001, "Why Do Countries Float the Way they Float?” Journal of Development Economics, 66:2, pp. 387-414.

Honohan, Patrick, and Anqing Shi, 2002, "Deposit Dollarization and the Financial Sector in Emerging Economies," World Bank, Policy Research Working Paper No. 2748, January. 
Ize, Alain, and Eduardo Levy Yeyati, 2001, "Financial Dollarization," Journal of International Economics, forthcoming.

Ize, Alain, and Eric Parrado, 2002, "Dollarization, Monetary Policy, and the Pass-Through," mimeo, International Monetary Fund.

Kaminsky, Graciela, and Carmen Reinhart, 1999, "The Twin Crises: The Causes of Banking and Balance-of-Payments Problems," The American Economic Review, 89 (June), pp. 473-500.

Krugman, Paul, 2001, "Notes on Depreciation, the Yen, and the Argentino," New York Times, December 28, http://www.wws.princeton.edu/ pkrugman/argentino.html.

Larraín, Felipe, and Andrés Velasco, 2001, "Exchange-Rate Policy in Emerging-Market Economies: The Case for Floating," Essays in International Economics No. 224, December.

Levy Yeyati, Eduardo and Federico Sturzenegger, 2001, "Deeds vs. Words: Classifying Exchange Rate Regimes," mimeo, http://www.utdt.edu/ ely.

McKinnon, Ronald, and Huw Pill, 1997, "Credible Economic Liberalizations and Overborrowing," American Economic Review, 87:2, pp. 189-193.

Mishkin, Frederic, 1999, "Lessons from the Asian Crisis," Journal of International Money and Finance, 18:4, pp. 709-723.

Mishkin, Frederic, 2001, "Financial Policies and the Prevention of Financial Crises in Emerging Market Countries," in Martin Feldstein (ed.), Economic and Financial Crises in Emerging Market Countries, University of Chicago Press, forthcoming.

Mishkin, Frederic, and Miguel Savastano, 2001, "Monetary Policy Strategies in Latin America," Journal of Development Economics, 66, pp. 415-444.

Mundell, Robert, 1961, "The Theory of Optimum Currency Areas," American Economic Review, 51 (September), pp. 657-665.

Obstfeld, Maurice, 1998, "The Global Capital Market: Benefactor or Menace?," Journal of Economic Perspectives, 12 (Fall): 9-30.

Obstfeld, Maurice, and Kenneth Rogoff, 1996, Foundations of International Macroeconomics, Cambridge, Mass.: MIT Press.

Obstfeld, Maurice, and Alan Taylor, 2002, "Globalization and Capital Markets," NBER Working Paper No. 8846, March, forthcoming in the NBER conference volume edited by Michael Bordo, Alan Taylor, and Jeffrey Williamson. 
Roubini, Nouriel, 2001, "Should Argentina Dollarize or Float? The Pros and Cons of Alternative Exchange Rate Regimes and Their Implications for Domestic and Foreign Debt Restructuring/Reduction," mimeo, New York University, December.

Stulz, René M., 1999, "Globalization of Equity Markets and the Cost of Capital," Journal of Applied Corporate Finance, Fall, pp. 8-25. 


\section{Universidad Torcuato Di Tella, Business School Working Papers}

\section{Working Papers 2003}

NN16 "Business Cycle and Macroeconomic Policy Coordination in MERCOSUR"

Martín Gonzalez Rozada (UTDT) y José Fanelli (CEDES).

No15 "The Fiscal Spending Gap and the Procyclicality of Public Expenditure"

Eduardo Levy Yeyati (UTDT) y Sebastián Galiani (UDESA).

No14 "Financial Dollarization and Debt Deflation under a Currency Board"

Eduardo Levy Yeyati (UTDT), Ernesto Schargrodsky (UTDT) y Sebastián Galiani (UDESA).

№13 " ¿ Por qué crecen menos los regímenes de tipo de cambio fijo? El efecto de los Sudden Stops", Federico Stuzenegger (UTDT).

№12 "Concentration and Foreign Penetration in Latin American Banking Sectors: Impact on Competition and Risk", Eduardo Levy Yeyati (UTDT) y Alejandro Micco (IADB).

№11 "Default 's in the 1990's: What have we learned?",

Federico Sturzenegger (UTDT) y Punan Chuham (WB).

№10 "Un año de medición del Indice de Demanda Laboral: situación actual y perspectivas",

Victoria Lamdany (UTDT) y Luciana Monteverde (UTDT)

N'09 "Liquidity Protection versus Moral Hazard: The Role of the IMF",

Andrew Powell (UTDT) y Leandro Arozamena (UTDT)

№8 "Financial Dedollarization: A Carrot and Stick Approach", Eduardo Levy Yeyati (UTDT)

No07 "The Price of Inconvertible Deposits: The Stock Market Boom during the Argentine crisis",

Eduardo Levy Yeyati (UTDT), Sergio Schmukler (WB) y Neeltje van Horen (WB)

NN06 "Aftermaths of Current Account Crisis: Export Growth or Import Contraction?",

Federico Sturzenegger (UTDT), Pablo Guidotti (UTDT) y Agustín Villar (BIS)

No5 "Regional Integration and the Location of FDI",

Eduardo Levy Yeyati (UTDT), Christian Daude (UM ) y Ernesto Stein (BID)

N04 "A new test for the success of inflation targeting",

Andrew Powell (UTDT), Martin Gonzalez Rozada (UTDT) y Verónica Cohen Sabbán (BCRA)

No03 "Living and Dying with Hard Pegs: The Rise and Fall of Argentina's Currency Board",

Eduardo Levy Yeyati (UTDT), Augusto de la Torre (WB) y Sergio Schmukler (WB)

No02 "The Cyclical Nature of FDI flows",

Eduardo Levy Yeyati (UTDT), Ugo Panizza (BID) y Ernesto Stein (BID) 
№1 "Endogenous Deposit Dollarization",

Eduardo Levy Yeyati (UTDT) y Christian Broda (FRBNY)

\section{Working Papers 2002}

№15 "The FTAA and the Location of FDI",

Eduardo Levy Yeyati (UTDT), Christian Daude (UM ) y Ernesto Stein ( BID)

No14 "Macroeconomic Coordination and Monetary Unions in a N-country World: Do all Roads

Lead to Rome?"

Federico Sturzenegger (UTDT) y Andrew Powell (UTDT)

№13 "Reforming Capital Requirements in Emerging Countries"

Andrew Powell (UTDT), Verónica Balzarotti (BCRA) y Christian Castro (UPF)

№12 "Toolkit for the Analysis of Debt Problems", Federico Sturzenegger (UTDT)

№11 "On the Endogeneity of Exchange Rate Regimes",

Eduardo Levy Yeyati (UTDT), Federico Sturzenegger (UTDT) e lliana Reggio (UCLA)

№10 "Defaults in the 90's: Factbook and Preliminary Lessons", Federico Sturzenegger (UTDT)

No09 "Countries with international payments ' difficulties: what can the IMF do?"

Andrew Powell (UTDT)

NN08 "The Argentina Crisis: Bad Luck, Bad Management, Bad Politics, Bad Advice",

Andrew Powell (UTDT)

N07 "Capital Inflows and Capital Outflows: Measurement, Determinants, Consequences",

Andrew Powell (UTDT), Dilip Ratha (WB) y Sanket Mohapatra (CU)

No06 "Banking on Foreigners: The Behaviour of International Bank Lending to Latin America, 1985-2000",

Andrew Powell (UTDT), María Soledad Martinez Peria (WB) y Ivanna Vladkova ( IMF)

No05 "Classifying Exchange Rate Regimes: Deeds vs. Words"

Eduardo Levy Yeyati (UTDT) y Federico Sturzenegger (UTDT)

NN04 "The Effect of Product Market Competition on Capital Structure: Empirical Evidence from the

Newspaper Industry", Ernesto Schargrodsky (UTDT)

N03 "Financial globalization: Unequal blessings",

Augusto de la Torre (World Bank), Eduardo Levy Yeyati (Universidad Torcuato Di Tella) y Sergio

L. Schmukler (World Bank)

N02 "Inference and estimation in small sample dynamic panel data models",

Sebastian Galiani (UdeSA) y Martin Gonzalez-Rozada (UTDT)

№1 "Why have poverty and income inequality increased so much? Argentina 1991-2002",

Martín González-Rozada, (UTDT) y Alicia Menendez, (Princeton University). 